\title{
Sneddon Syndrome: Livedo Reticularis and Ischemic Stroke
}

\section{Sneddon Sendromu:Livedo Retikülaris ve Iskemik Inme}

Ahmet Bugrul ${ }^{1}$,

Hasan Huseyin Kozak ${ }^{1}$, Mustafa Altas ${ }^{1}$

${ }^{1}$ Necmettin Erbakan University, Meram Faculty of Medicine, Department of Neurology, Konya, Turkey

Geliş Tarihi/Received: 4 June 2020 Kabul Tarihi/Accepted: 21 September 2020

Address correspondence to: Ahmet Bugrul, Necmettin Erbakan University, Meram Faculty of Medicine, Department of Neurology, Konya, Turkey

e-mail: ahmet.bugrul@gmail.com

\section{ORCID}

Ahmet Bugrul

https://orcid.org/0000-0002-6208-2553

Hasan Huseyin Kozak

https://orcid.org/0000-0001-6904-8545 Mustafa Altas

https://orcid.org/0000-0003-3011-1062

\begin{abstract}
Öz
Sneddon sendromu(SS) tekrarlayan iskemik ataklar ile giden nadir görülen bir vaskülopatidir. Kesin bir tedavi yöntemi olmamakla birlikte antiagregan, antikoagülen ve immünsüpresan tedaviler önerilmektedir. Bu raporda SS'li bir hastanın tanı ve tedavi sürecini sunduk. 44 yaşında kadın hasta sağ tarafında geçici his kaybı ve eşlik eden konuşma bozukluğu ile başvurdu. Nörolojik muayanesinde sağda santral fasiyel asimetri ve konuşmasında hafif dizartri vardı. Difüzyon MR'nda sol lentifom nukleus ve kaudat nükleus başında akut iskemik değişiklik mevcuttu. Kraniyal MR'da perivasküler iskemik gliotik değişiklikler ve yaygın kortikal serebral atrofi mevcuttu. Her iki ayakta livedoretikülaris görünümü olan hastaya cilt biyopsisi yapıldı. Cilt biyopsisi vaskülopati ile uyumlu geldi. Ayaklarda livedo retikülaris, periventriküler iskemik gliotik değişikler ve iskemik atak öyküsü olan hasta SS olarak kabul edildi. Antifosfolipid antikoru negatif olan hasta ikili antiagregan ile takip edildi. Ikili antiagregan ile bir sene takip edilen hastada yeni atak görülmedi. Tekrarlayan iskemik olayları olan ve antifosfolipit antikoru negatif saptanan SS hastalarında ikili antiagregan tedavi düşünülebilir.

Anahtar Kelimeler: Antifosfolipit antikor, livedo retikülaris, inme, sneddon sendromu, vaskülopati Abstract

Sneddon syndrome(SS) is a rare, progressive vasculopathy with recurrent ischemic attacks. There is no specified treatment recommendation, various treatment methods such as anticoagulants, antiaggregants, and immunosuppressions are recommended. In this report, we presented diagnosis and treatment process of a patient with SS. A 44-years-old woman who applied with a temporary numbness on her right side and speech disorder. In her neurological examination, there was central facial asymmetry on the right and mild dysarthria in his speech. In cranial diffusion MR, there was an acute ischemic change in the left lentiform nucleus and at the head of the caudate nucleus. In cranial MR, there were perivascular ischemic gliotic changes and diffuse cerebral cortical atrophy. The patient underwent a skin biopsy to have livedo reticularis-like lesions on both legs. Skin biopsy was compatible with vasculopathy. Due to the ischemic attack, periventricular ischemic changes, and livedoreticularis, the patient was accepted as SS. Since the antiphospholipid antibodies (APL) were negative, that she was followed up with dual antiplatelet therapy. There was no new attack within a year with dual therapy. Dual antiplatelet therapy may be used in SS patients with recurrent ischemic events and negative APL.
\end{abstract}

Key words: Antiphospholipid antibody, livedo reticularis, sneddon syndrome, stroke vasculopathy
Cite this article as: Bugrul $\mathrm{A}$, Kozak, $\mathrm{HH}$, Altas $\mathrm{M}$. Sneddon Syndrome: Livedo Reticularis and Ischemic Stroke. Selcuk Med J 2021;37(1): 80-82

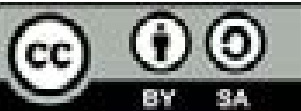

Disclosure: None of the authors has a financial interest in any of the products, devices, or drugs mentioned in this article. The research was not sponsored by an outside organization. All authors have agreed to allow full access to the primary data and to allow the journal to review the data if requested. 


\section{INTRODUCTION}

Sneddon Syndrome (SS) is a progressive vasculopathy that affects small and medium vessels and is characterized by livedoreticularis and neurological symptoms (1). It is generally seen in women between the ages of 20-42 in 4 million (2). It was first described by Kimming in 1959 and reported by Sneddon in 1965 as a disease accompanied by livedo reticularis and numerous cerebrovascular events $(3,4)$. In this report, we presented diagnosis and treatment process of a patient with Sneddon syndrome.

\section{CASE}

A44-year-old woman who applied to the emergency room with a temporary numbness on her right side and speech disorder. Her complaints started suddenly and lasted for about 2 hours. She has known hypertension for 6 years. She was followed up due to perivascular ischemic-gliotic lesions and dizziness attacks several times a year. She was using 100 mg/day ASA. On neurological examination, cranial nerve examination was normal except for central facial asymmetry on the right. Muscle strength was normal in the lower and upper extremities. No pathological reflex was detected. The speech was mildly dysarthric. Other neurological examination findings were evaluated as normal. Both legs had livedo reticularis-like lesions (figure 1). Acute ischemia was detected in the left caudate nucleus and lentiform nucleus in diffusion MRI (figure 2). There were periventricular ischemic gliotic changes and diffuse cerebral cortical atrophy in cranial MRI. ANA, anti-dsDNA, anti-cardiolipin $\lg M$, and $\lg G$ were negative. Protein $C$ protein $S$, antithrombin III were within normal limits. Within

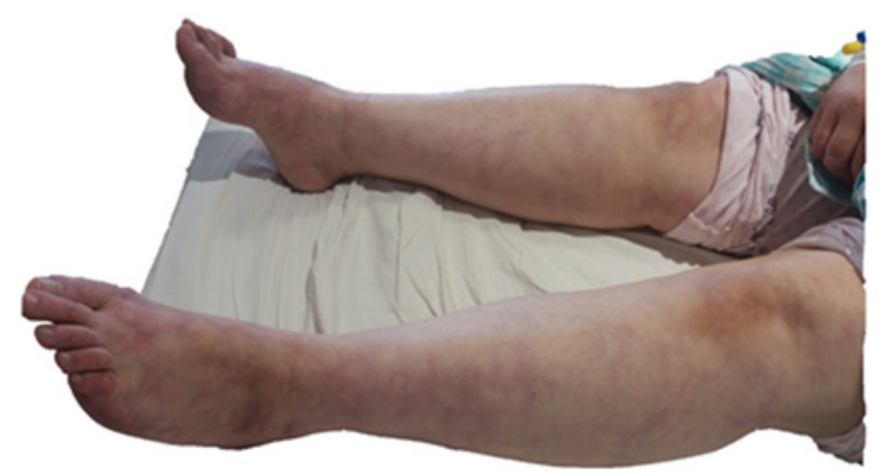

Figure 1. Livedo reticularis-like appearance on both legs

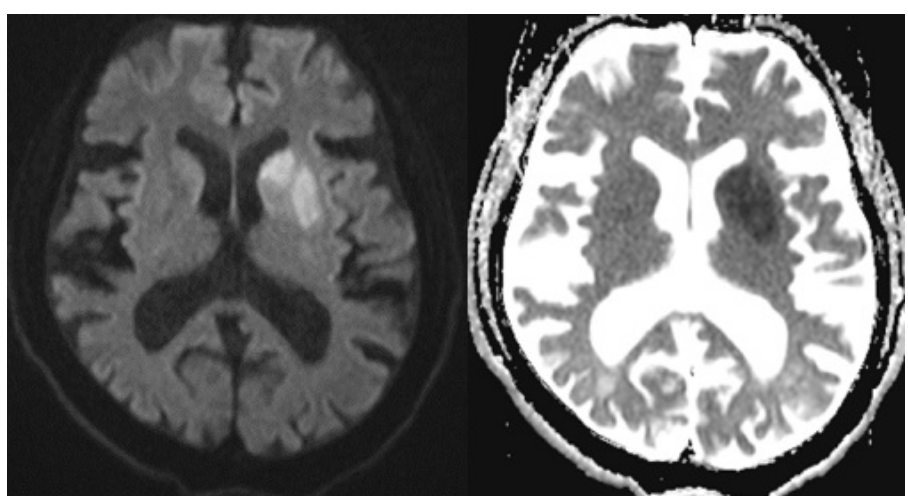

Figure 2. Acute ischemic change in the left caudate nucleus and lentiform nuclei in diffusion MRI

the framework of young cerebrovascular disease examination, digital subtraction angiography (DSA) was performed especially to examine vasculitic conditions. As a result of DSA, the vascular network was observed in thin and distal occludes (Figure 3). In skin biopsy performed for vasculitis, IgG, $\lg \mathrm{M}$, and $\lg \mathrm{A}$ were negative in the basal layer and stratified squamous epithelium. C3 was found to be positive in the upper dermis and perivascular. Fibrin accumulation in the vascular walls and surrounding histiocytes and lymphocytes were observed. The patient, whose current pathological specimen findings were compatible with livedoid vasculopathy. Due to the ischemic attack, periventricular ischemic changes, and livedoreticularis, the patient was accepted as SS. The patient, whose APL was negative, was discharged with $75 \mathrm{mg} /$ day clopidogrel and $100 \mathrm{mg} /$ day ASA.

\section{DISCUSSION}

SS is a progressive vasculopathy that involves

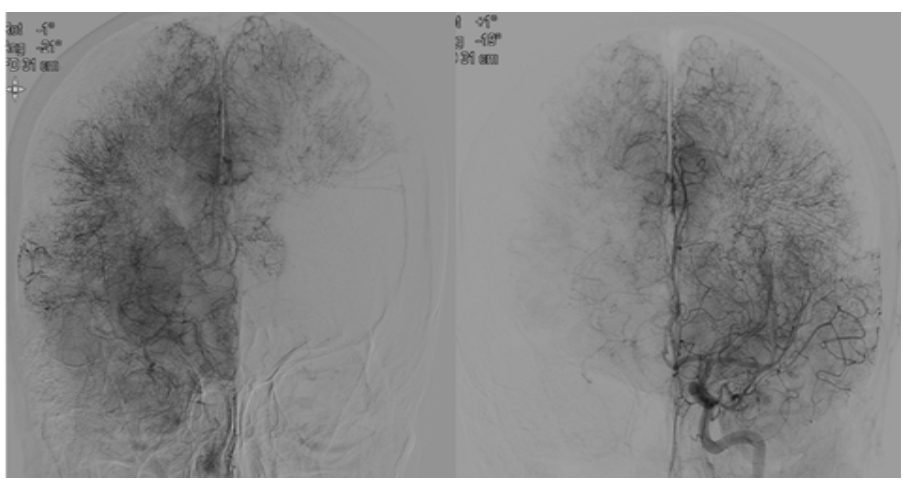

Figure 3. Both ACA, MCA, and PCA distal thin and occlude in DSA 
small and medium-sized vessels(1). SS may have various neurological symptoms such as headache, epilepsy, transient ischemic attack, ischemic and hemorrhagic stroke. Although there is no specified treatment recommendation, various treatment methods such as anticoagulants, antiaggregants, and immunosuppressions are recommended. Antiaggregant therapy may be more effective in patients with negative APL and anticoagulant therapy in those with positive APL. (5). High-dose warfarin with international normalized ratio (INR) $>3$ is preferable for APL positive patients. But the treatment of APL negative SS is controversial. Both antiplatelet agents (aspirin and clopidogrel) and antithrombotic agents (warfarin) have a similar protective effect in aPL negative patients. Due to a higher risk of hemorrhagic complications under anticoagulant therapy, antiplatelet agents may consider as first-line therapy(6). The effectiveness of immunosuppressant treatments has not been proven yet (5). Few studies have found a significant reduction in skin lesions of patients given intravenous immunoglobulin and a marked improvement in the quality of life(7). In another study, neurological and cognitive recovery was noted in a patient who was given monthly intravenous cyclophosphamide for 8 months(8).

Since APL was found to be negative in our case, $75 \mathrm{mg} /$ day clopidogrel was added to the patient who had previously used $100 \mathrm{mg} /$ day ASA. No additional attacks were observed during the one-year follow-up. Treatment of SS patients is controversial and more studies are needed.

Conflict of interest: Authors declare that there is no conflict of interest between the authors of the article.

Financial conflict of interest: Authors declare that they did not receive any financial support in this study.
Address correspondence to: Ahmet Bugrul, Necmettin Erbakan University, Meram Faculty of Medicine, Department of Neurology, Konya, Turkey

E-mail: ahmet.bugrul@gmail.com

Phone number: +90-332 2237344

\section{REFERENCES}

1. Champion $\mathrm{RH}$, Rook A. Cutaneous arteriolitis. Proc R Soc Med 1960;53(7):568.

2. Frances C, Papo T, Wechsler B, et al. Sneddon syndrome with or without antiphospholipid antibodies. A comparative study in 46 patients. Medicine (Baltimore) 1999;78(4):20919.

3. Kimming J. Arteriolopathie: Livedo resemosa. Dermatol Wochenschr 1959;139:211.

4. Sneddon I. Cerebro-vascular lesions and livedo reticularis. British Journal of Dermatology 1965;77(4):180-5.

5. Wu S, Xu Z, Liang H. Sneddon's syndrome: A comprehensive review of the literature. Orphanet $J$ Rare Diseases 2014;9(1):215.

6. Bottin L, Francès $C$, de Zuttere $D$, et al. Strokes in $S$ neddon syndrome without antiphospholipid antibodies. Annals of Neurology 2015;77(5):817-29.

7. Monshi B, Posch C, Vujic I, et al. Efficacy of intravenous immunoglobulins in livedoid vasculopathy: Long-term followup of 11 patients. J Am Acad Dermatol 2014;71(4):738-44.

8. Hannon PM, Kuo SH, Strutt AM, et al. Improvement of neurological symptoms and memory and emotional status in a case of seronegative sneddon syndrome with cyclophosphamide. Clin Neurol Neurosurg 2010;112(6):5447. 